\begin{tabular}{|l|l|l|l|l|}
\hline Cuadernos de Investigación Geográfica & 2001 & $\mathbf{N}^{\mathrm{o}} 27$ & pp. 163-178 & ISSN 0211-6820 \\
\hline
\end{tabular}

(c) Universidad de La Rioja

\title{
LATE HOLOCENE EVOLUTION OF THE LOWER TAGUS ALLUVIAL PLAIN AND HEAVY METALS CONTENT: PRELIMINARY RESULTS
}

C. RAMOS (1)

E. REIS ${ }^{(1)}$

A. RAMOS PEREIRA ${ }^{(1)}$

T. M. AZEVEDO ${ }^{(2)}$

E. NUNES (2)

M. C. FREITAS ${ }^{(2)}$

C. ANDRADE (2)

(1) Centro de Estudos Geográficos, Universidade de Lisboa, Faculdade de Letras, 1600-214 Lisboa, Portugal.

(2) Centro de Geología, Universidade de Lisboa, 1600-214 Lisboa, Portugal.

ABSTRACT: This paper aims to contribute to the fluvial dynamic kno wledge of the Lower Tagus during the late Holocene. Two cores were done in selected geomorphological positions at the alluvial plain. Each ten cen timeters of sediments were submitted to sedimentological and geochemical analyses in order to identify human contamination by heavy metals, sedi mentation rates and environmental changes in the main channel position. The main conclusions are: (1) The witness of the lateral migration of the fluvial channel; (2) The very irregular sedimentation rate, from $3 \mathrm{~mm}$ per year to $0.1 \mathrm{~mm}$ per year; (3) The diversified contamination of fluvial sedi ments and fluvial channels by heavy metals, namely $\mathrm{Cu}$ due to cooper sul phate vineyards and $\mathrm{Pb}$ due to petrol and $\mathrm{Cr}$ from the tanning industries.

RESUMEN: Este trabajo pretende contribuir al conocimiento de la dinámica fluvial del curso inferior del río Tajo durante el Holoceno final. Se han realizado dos sondeos en lugares seleccionados de la llanura aluvial. Muestras del sedimento obtenidas cada diez centímetros se han anali zado con el fin de identificar la contaminación humana con metales pesados, las tasas de sedimentación y posibles cambios en la posición del cauce principal. Las conclusiones más importantes son: (1) La prueba de la exis tencia de migración lateral del cauce fluvial; (2) La gran irregularidad de la tasa de sedimentación, que varía entre 0.1 y 3 mm por año; (3) La varia da contaminación de los sedimentos fluviales y de los cauces por metales pesados, especialmente $\mathrm{Cu}$ debido a la aplicación de sulfato de cobre en viñedos, $\mathrm{Pb}$ debido al petróleo, y Cr por las industrias de curtidos.

Key-words: Holocene, Sedimentation, Contamination, Heavy metals, Tagus River, Portugal.

Palabras clave: Holoceno, Sedimentación, Contaminación, Metales pesados, Río Tajo, Portugal. 


\section{Geological and geomorphological framework}

This work has been undertaken in the scope of the Praxis XXI Project untitled "An interdisciplinary approach to flood risk evaluation - hydrology, geomorphology and sedimentology of the Douro, Tagus and Sado Basins (IDAFRE)".

This paper aims to contribute to the fluvial dynamic knowledge of the Lower Tagus during the late Holocene, based on the sedimentological and geochemical analysis of the sediments from two cores. The cores were done in different geomorphologic positions chosen in the alluvial plain.

The Tagus hydrographic basin has $80,629 \mathrm{~km}^{2}\left(55,769 \mathrm{~km}^{2}\right.$ in Spain and $24,860 \mathrm{~km}^{2}$ in Portugal; Figure 1). In Portugal, this basin shows a strong morphologic and climatic dissymmetry between the two margins. The northern margin is more rainy (900$2,000 \mathrm{~mm}$ per year) than the southern $(500-900 \mathrm{~mm}$ per year). This contrast reflects a set of geomorphological features namely the Central Cordillera in the Hercynian Massif (granites and shales of the Central Iberian Zone) and the small limestone mountains (Aire, Candeeiros and Montejunto) in the Mesocenozoic Sedimentary Basin.

The southern margin is lower and has several planation surfaces that cut the Hercynian and the Precambrian rocks (migmatitic shales and granites of the Ossa Morena Zone) and also the Miopliocene sediments (sandstones, conglomerates and clays with limestone layers) of the Tagus Cenozoic Sedimentary Basin. The sedimentary sequence is composed by 300 to $700 \mathrm{~m}$ thickness of continental siliciclastics sedi-

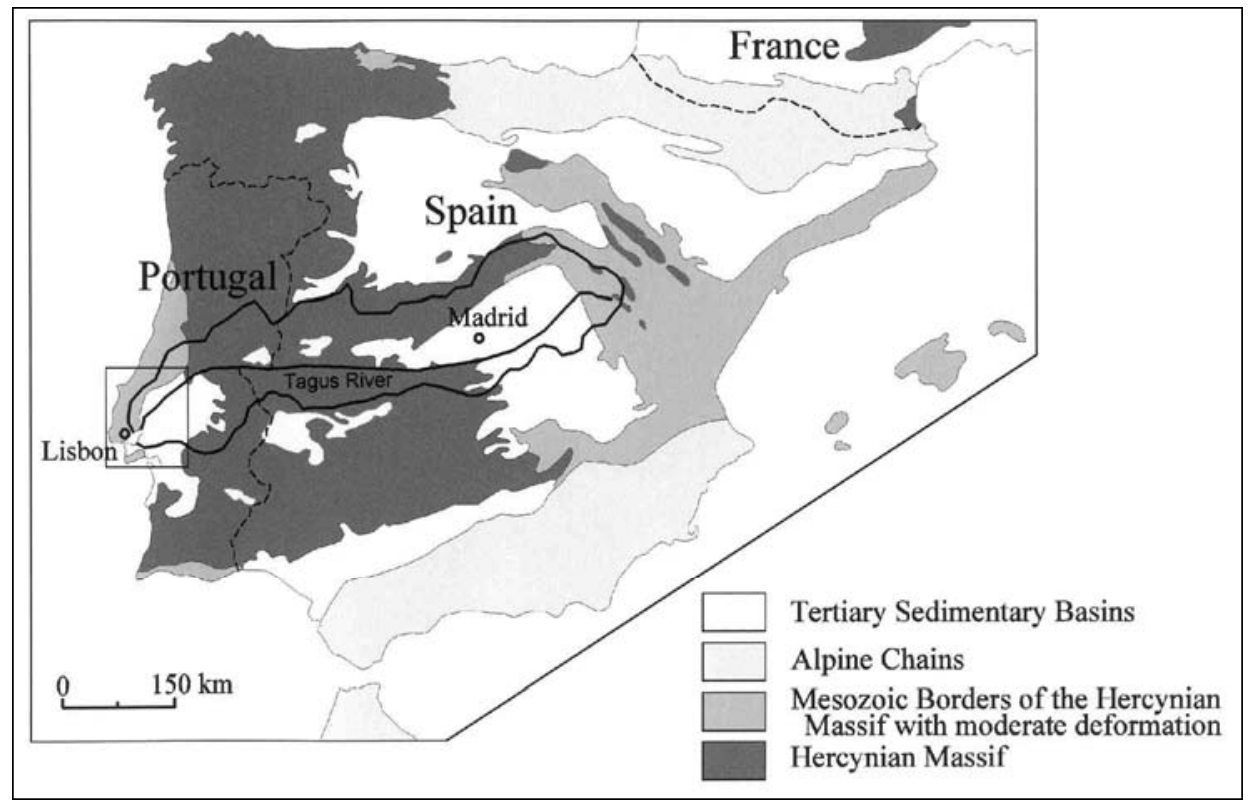

Figure 1. Structural framework of Tagus drainage basin (the square represents the more detailed map of figure 2). 


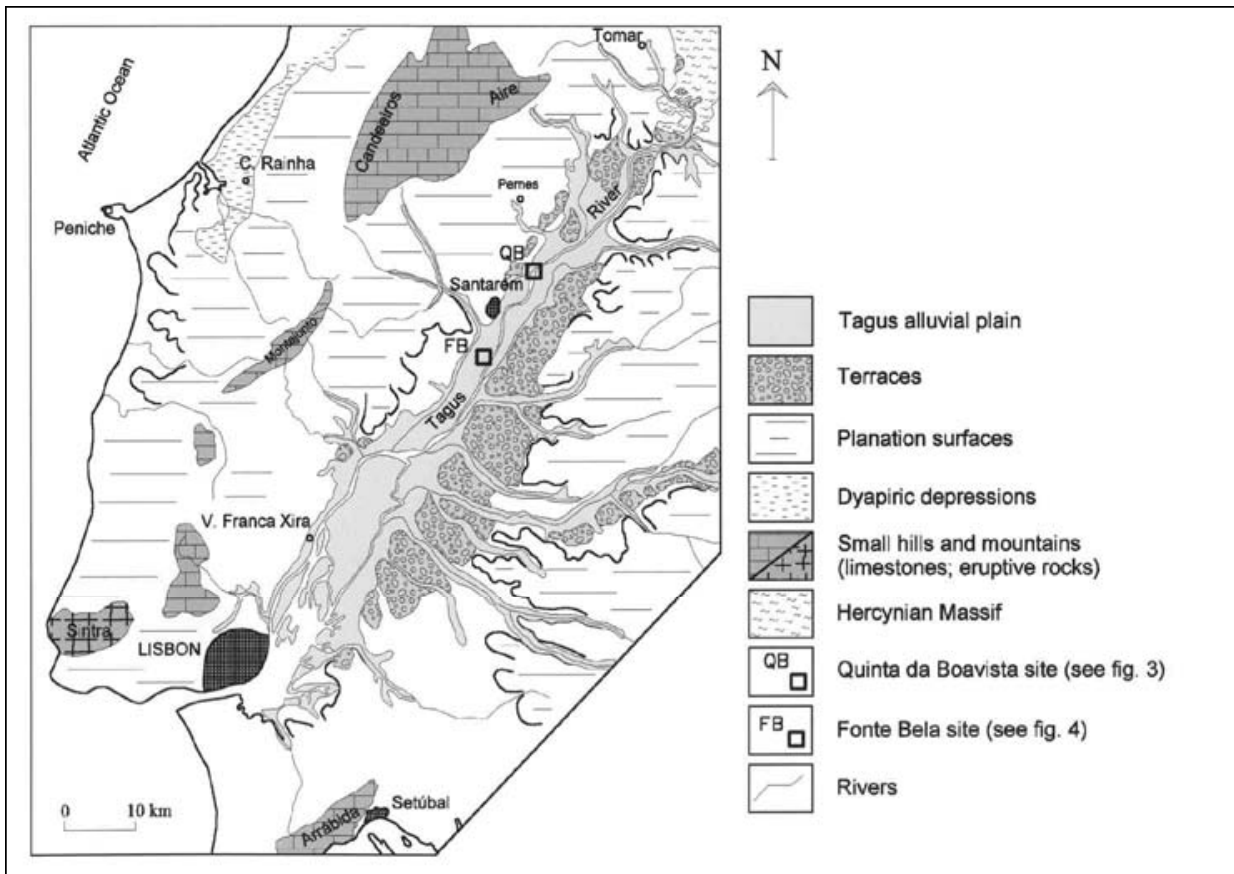

Figure 2 - Geomorphological framework of the Lower Tagus Basin.

(D.B. Ferreira, 1980, simplified)

ments, on both banks of the river. This sequence is best developed on the left bank of the Tagus (Figure 1), while the right bank has lutitic and carbonated sediments. The sediments thickness growths towards the center of the basin, from $400 \mathrm{~m}$ at Pernes to 500$600 \mathrm{~m}$ at Ota (Barbosa, 1985) and about 1200m in the Peninsula of Setúbal or near V.F. de Xira, near the depocentre of the Basin.

The diversified lithology of the Basin frame area as well as the great thickness and the low resistance to erosion of the tertiary infilling are responsible by the abundant and diversified nourishment of the Basin during the Pleistocene and the Holocene.

Since the infilling reflects the geological framework of the Basin, its knowledge is specially important to identify the source of the heavy metals concentrations and to distinguish what is due to anthropogenic action.

The Tagus valley can be divided in two geomorphologic sections. In the upstream section, between the Spanish border and Almourol, crossing the Hercynian Massif, the ENE-WSWvalley is deep and narrow, in special when it crosses quartzitic ridges or more resistant granites, and broadens when crossing small tectonic depressions. In the second section the valley broadens remarkably, since the river enters the wide Cenozoic Sedimentary Basin, flowing from NE to SW as far as Lisbon. This section is known as the Lower Tagus (LT). The valley is then dissymmetric because of the larger terraces on the left bank (Figure 2), probably related to the Lower Tagus fault. 
The LT alluvial plain is 5 to $15 \mathrm{~km}$ width and it gets the greater floods of Portugal, spreading over more than $800 \mathrm{~km}^{2}$.

\section{Methodology}

The two core sites have been choose in different geomorphological positions in the LT alluvial plain (Figure 2): the Quinta da Boavista site is placed in the right bank of the Tagus main channel (Figure 3), while the Fonte Bela site, also in the right margin, is 2.5 $\mathrm{km}$ far from the main channel (Figure 4).

The detailed alluvial plain morphology that frame the Quinta da Boavista core (Figure 3) shows several elongated lower areas that have been use to built ditches to improve the alluvial plain drainage and to irrigate the near agricultural areas. These lower areas witness the several positions of the Tagus main channel in its lateral migration, from east to west. On the opposite, the Fonte Bela core (Figure 4) was taken in an area with more calm sedimentation, between the present bars and the palaeochannel of the river.

The coring sites were coordinated and connected to the UTM grid and Portuguese vertical Datum (mean sea level - msl). In the graphs of the sedimentological and geochemical data, the zero meters correspond to $6.5 \mathrm{~m}$ above msl, at Quinta da Boavista (where the core reached $3.70 \mathrm{~m}$ ) and to $5.32 \mathrm{~m}$ above msl at Fonte Bela (where the core reached $7.40 \mathrm{~m})$.

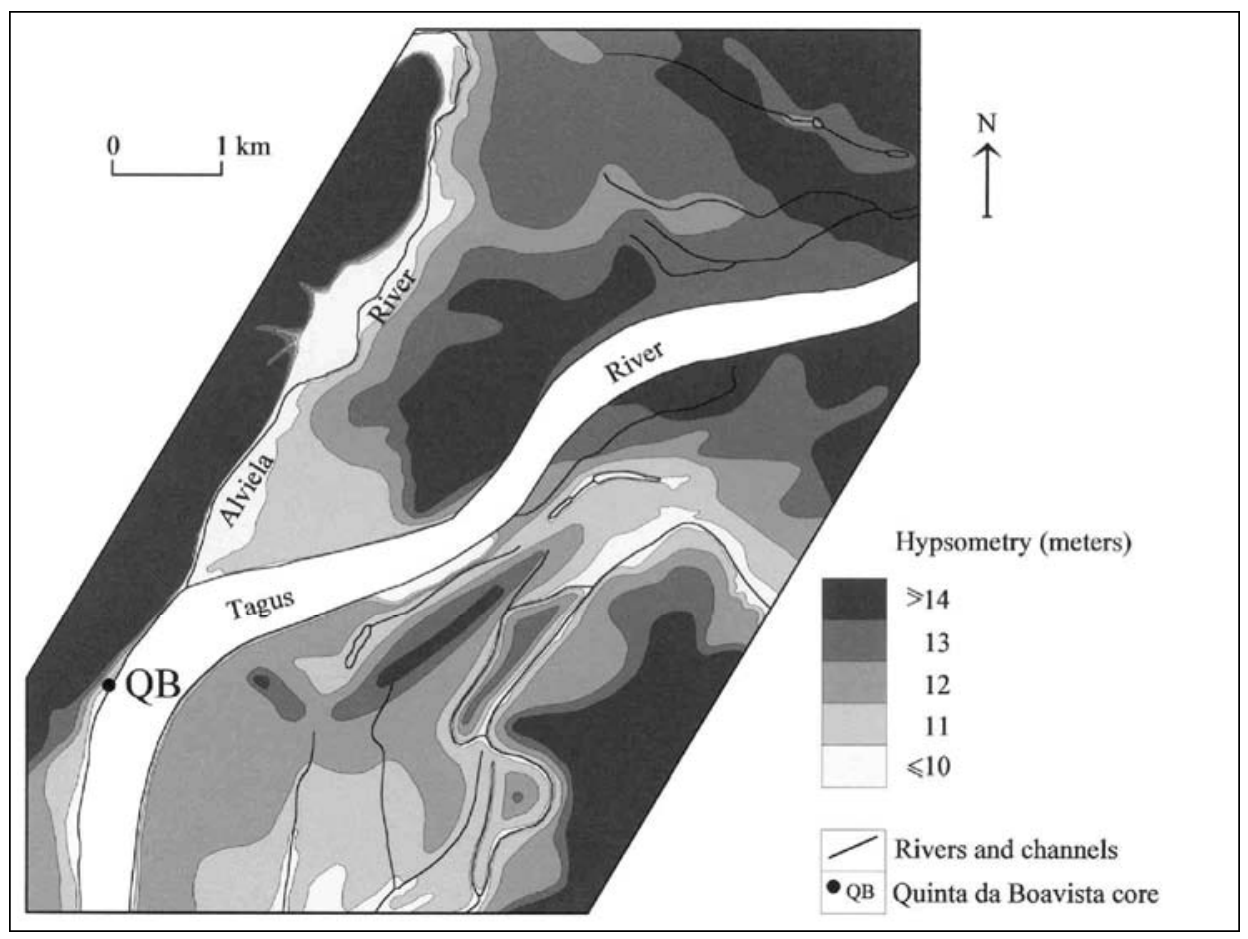

Figure 3 - Morphological frame of Quinta da Boavista site. 


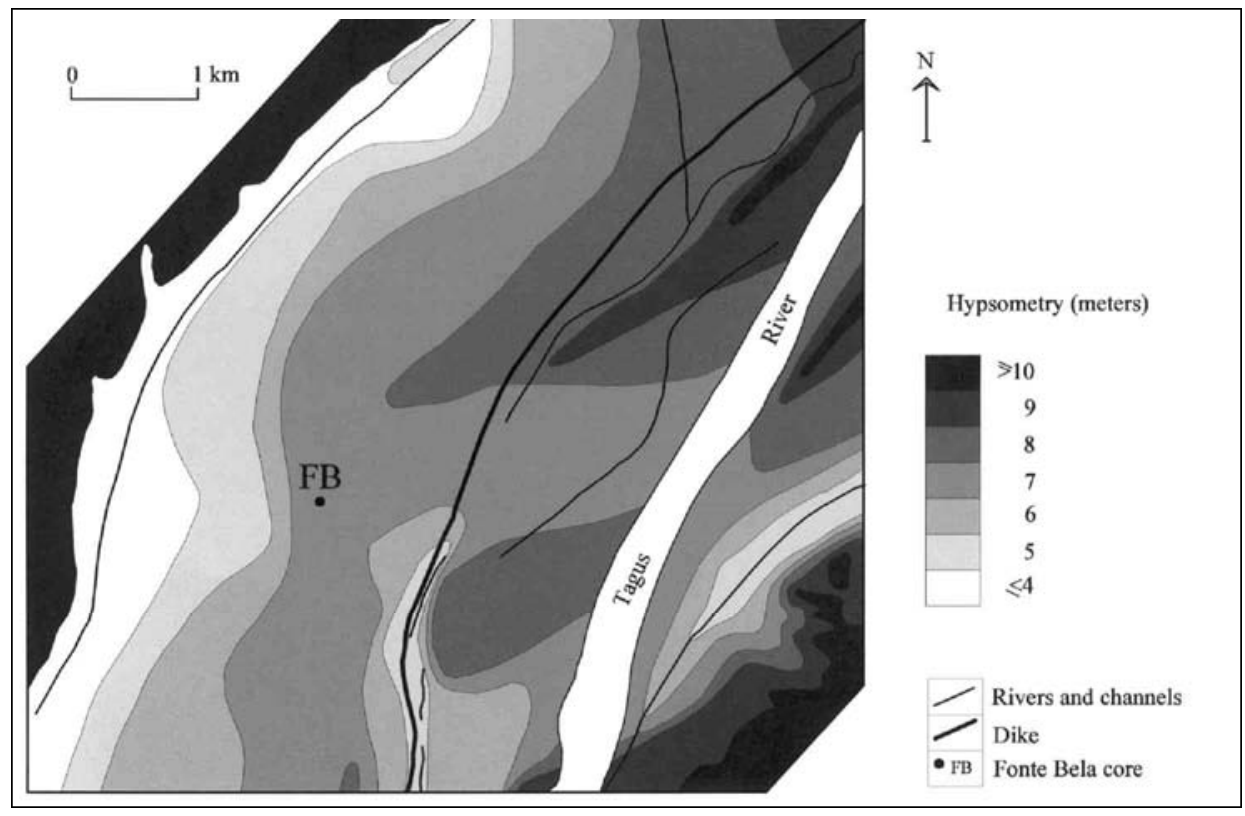

Figure 4 - morphological frame of Fonte Bela site.

At Fonte Bela, between 0 and $2.50 \mathrm{~m}$, sampling was carried in an irrigation ditch wall using $20 \mathrm{~cm}$ long and $5 \mathrm{~cm}$ diameter PVC tubes. From $2.50 \mathrm{~m}$ to $7.40 \mathrm{~m}$, the sediment core was taken using $50 \mathrm{~mm}$ and $35 \mathrm{~mm}$ diameter steel gauge augers, below ground surface where lateral and bottom attrition prevented further penetration. This last procedure was also used at Quinta da Boavista. The sediment cores were wrapped in plastic foil, transferred to plastic guttering, and taken for laboratory analysis. In the laboratory, each cored segment was opened longitudinally and described macroscopically. Both halves were then sub-sampled for sedimentological and geochemical analyses.

Eighty-six (thirty eight at Quinta da Boavista and forty eight at Fonte Bela) whole rock (dried) sediment samples were analyzed by fusion inductively coupled plasma emission / mass spectrometry (ICP/MS) and instrumental neutron activation analysis (Activation Laboratories Ltd., Canada) for 37 major and several trace elements. Nine heavy metals have been selected ( $\mathrm{As}, \mathrm{Au}, \mathrm{Co}, \mathrm{Cr}, \mathrm{Cs}, \mathrm{Cu}, \mathrm{Fe}, \mathrm{Pb}$ e $\mathrm{Zn}$ ) to illustrate the main kind of variation along the core or to show the surface contaminations due to human activity. We must emphasize that some heavy metals, for example the $\mathrm{Hg}$, was not taken into account because its tenor was always below the detection threshold.

The sediment samples collected for dating consisted of thin $(1-2 \mathrm{~cm})$ slices of muds. Samples were dated by standard accelerated mass spectrometry (AMS) and ${ }^{14} \mathrm{C}$ radiometric determination at Beta Analytic Inc., USA. Calibration of radiocarbon dates was performed according to Vogel et al. (1993), Talma and Vogel (1993) and Stuiver et al. (1993). 


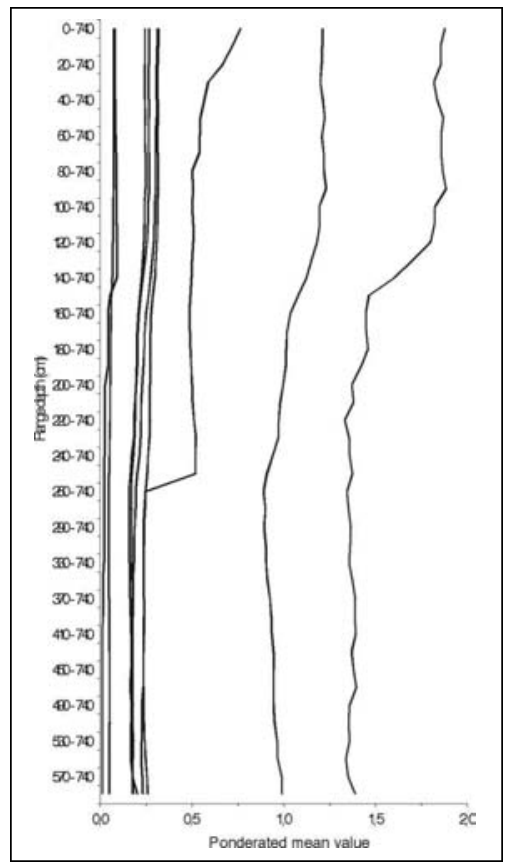

Figure 5 - Geochemical background value definition of the nine heavy metals at Fonte Bela.

The sedimentological study included the granulometric analysis of the whole sample. The sandy fraction (coarser than $63 \mu \mathrm{m}$ ) was sieved at $1 \mathrm{f}$ interval. The textural classification follows Folk \& Ward (1957) and statistics of grain size distribution were calculated using the method of moments. The finer grained sediments ( 3 and $4 \mathrm{f}$ ) were sampled for heavy mineral suites, which were then mounted on thin plates for microscopic observation. The silty-clayed fraction (finer than $63 \mu \mathrm{m}$ ) was analyzed by a Philips X'Pert difractometer with the data being treated by a Philips Profile Fit programme. The mineralogy of the clays was identified and quantified along the profiles.

The identification of the contaminants in the sediments of the alluvial plain and in those of the main channel assumes that the geochemical background is known. These values correspond to the heavy metal tenor in natural conditions, i.e., without relevant influence of human activities. Nevertheless, such values were never establishes before for the LT.

To establish the geochemical background of each heavy metal we must know its depth variation. These values can be obtained by simple statistical procedures.

As the heavy metals tenors depend mainly of the silty-clayed fraction, those values were weighed by the percentage of each fraction to eliminate silty-clayed influence.

The geochemical background behavior was established using the two cores, after the definition of the general pattern. For each chemical element the average tenor was calculated, first taking into account the all cores and after the surface layers were removed 
successively until the mean value of each element reached stabilization. At this point the geochemical background was found (Figure 5). This methodology was applied to both cores. The heavy metal content lower with deep and the average values of each element get closer (Figure 6), reaching the background values. The lowest and the stabilized values were achieved in the deeper sedimentologic unit (250 to $740 \mathrm{~cm}-$ unit I) of Fonte Bela core (Figure 5). The analysis of data shows that there is a heavy metal contamination of the alluvial sediments when its tenors exceed three standard deviations the geochemical background. This procedure agrees with the conclusions present in the study of the marsh sediments of the Tagus estuary (Freitas et al, 1999).

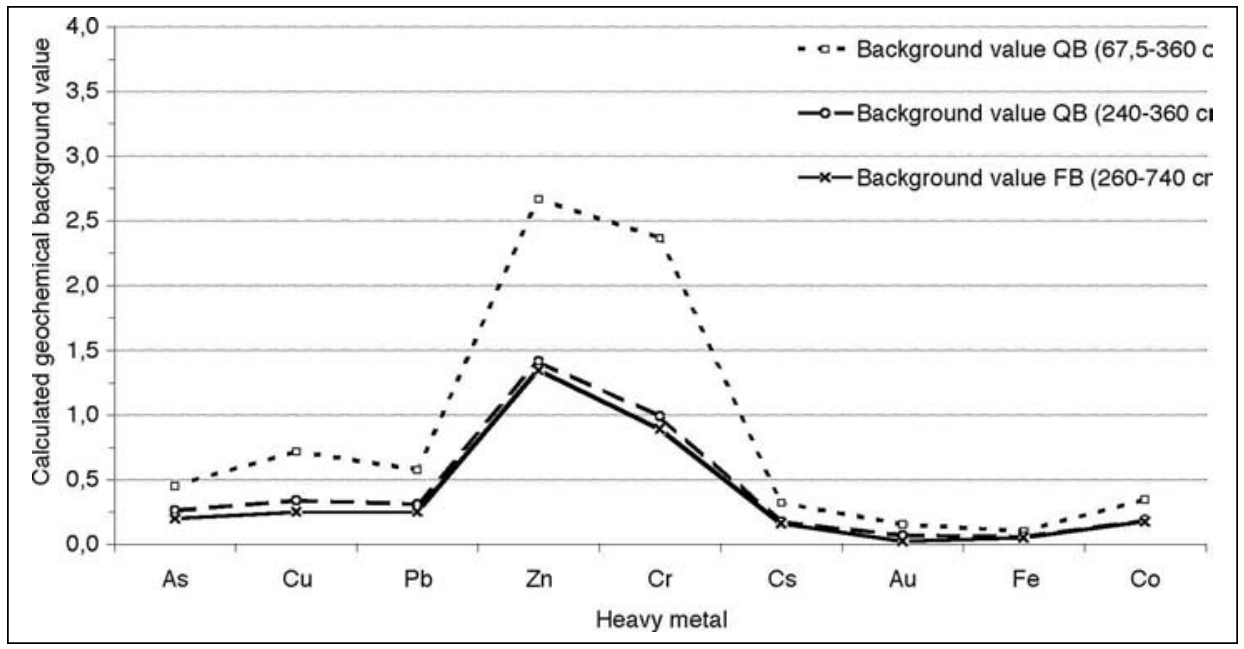

Figure 6 - Comparision of geochemical background values from Fonte Bela (FB) core and those founded in Quinta da Boavista (QB9 core using average values for two different range depths.

\section{Sedimentological and geochemical analysis of Fonte Bela core}

The sedimentological study of Fonte Bela core allowed the definition of three sedimentary units (Units I to III) - table 1 and figure 7.

Unit I $(740-250 \mathrm{~cm})$ - The basal unit consists essentially of mud and occasionally of muddy sands, the mud content averaging $90 \%$ of the total sample (between $44 \%$ and $99 \%$ ). The topmost sample corresponds to muddy sand and most probably represents a lag deposit resting in the bottom of the ditch.

Unit II $(250-90 \mathrm{~cm})$ - The intermediate unit consists of muddy sands, the mud content averaging $21 \%$ of the total sample (between $12 \%$ and $32 \%$ ). The sand component is always fine, well sorted in its lower section and moderately sorted in the upper section (Figure 7); sorting decreases systematically up core, more pronouncedly above $135 \mathrm{~cm}$, concomitant with increasing mean diameter (Figure 7). The skewness index remains fairly constant and negative across this unit. 
C. Ramos, E. Reis, A. Ramos Pereira, T.M. Azevedo, E. Nunes, M.C. Freitas \& C. Andrade

\begin{tabular}{|c|c|c|c|c|c|c|c|c|c|c|}
\hline \multirow[b]{2}{*}{ Depth $(\mathrm{cm})$} & \multirow[b]{2}{*}{$\begin{array}{l}\text { Silt+clay } \\
(\%)\end{array}$} & \multicolumn{4}{|c|}{ Chalcophiles } & \multicolumn{2}{|c|}{ Lithophiles } & \multicolumn{3}{|c|}{ Siderophiles } \\
\hline & & As (ppm) & $\begin{array}{c}\mathrm{Cu} \\
(\mathrm{ppm})\end{array}$ & $\begin{array}{c}\mathrm{Pb} \\
(\mathrm{ppm})\end{array}$ & $\begin{array}{c}\mathrm{Zn} \\
(\mathrm{ppm})\end{array}$ & $\begin{array}{c}\mathrm{Cr} \\
(\mathrm{ppm})\end{array}$ & Cs (ppm & Au (ppb) & $\begin{array}{l}\mathrm{Fe} \\
(\%)\end{array}$ & $\begin{array}{c}\mathrm{Co} \\
(\mathrm{ppm})\end{array}$ \\
\hline $0-10$ & 35,4 & 11,6 & 104 & 13 & 104 & 45 & 10 & 6 & 2,85 & 8 \\
\hline $10-20$ & 37,0 & 14.4 & 112 & 13 & 64 & 48 & 10 & 1 & 2,80 & 8 \\
\hline $20-30$ & 25,9 & 13,0 & 111 & 12 & 95 & 40 & 10 & 1 & 2,74 & 9 \\
\hline $30-40$ & 64,3 & 13,2 & 102 & 11 & 62 & 41 & 10 & 1 & 2,64 & 9 \\
\hline $40-50$ & 60,6 & 13,1 & 85 & 13 & 25 & 48 & 10 & 1 & 2,91 & 9 \\
\hline $50-60$ & 23,3 & 13,4 & 15 & 13 & 57 & 43 & 10 & 1 & 2,74 & 8 \\
\hline $60-70$ & 58,3 & 17,3 & 41 & 11 & 102 & 46 & 10 & 1 & 3,02 & 10 \\
\hline $70-80$ & 39,7 & 13,7 & 85 & 12 & 61 & 47 & 11 & 2 & 2,96 & 9 \\
\hline $80-90$ & 59,5 & 11,2 & 13 & 14 & 72 & 46 & 10 & 5 & 2,86 & 9 \\
\hline $90-100$ & 15,8 & 10,2 & 12 & 8 & 66 & 42 & 10 & 1 & 2,59 & 9 \\
\hline $100-110$ & 34,5 & 8,0 & 11 & 10 & 64 & 36 & 9 & 1 & 2,31 & 7 \\
\hline $110-120$ & 20,4 & 9,1 & 10 & 7 & 53 & 35 & 8 & 1 & 2,19 & 7 \\
\hline $120-130$ & 14,0 & 8,1 & 9 & 7 & 73 & 32 & 9 & 1 & 2,24 & 7 \\
\hline $130-140$ & 13,6 & 7,8 & 9 & 7 & 71 & 29 & 8 & 1 & 2,01 & 6 \\
\hline $140-150$ & 11,5 & 7,5 & 8 & 7 & 70 & 30 & 7 & 15 & 1,94 & 6 \\
\hline $150-160$ & 12,1 & 8,6 & 8 & 8 & 25 & 29 & 7 & 5 & 2,01 & 6 \\
\hline $160-170$ & 18,8 & 8,6 & 8 & 6 & 25 & 29 & 7 & 1 & 1,98 & 7 \\
\hline $170-180$ & 21,7 & 7,8 & 8 & 8 & 25 & 26 & 7 & 1 & 1,88 & 6 \\
\hline $180-190$ & 26,9 & 9,1 & 10 & 7 & 69 & 30 & 7 & 1 & 2,10 & 6 \\
\hline $190-200$ & 23,0 & 9,4 & 9 & 8 & 64 & 31 & 8 & 12 & 2,10 & 6 \\
\hline $200-210$ & 21,7 & 8,4 & 8 & 6 & 25 & 31 & 8 & 1 & 2,09 & 7 \\
\hline $210-220$ & 27,6 & 7,2 & 9 & 7 & 72 & 33 & 8 & 1 & 2,23 & 7 \\
\hline $220-230$ & 32,1 & 9,0 & 10 & 9 & 25 & 34 & 8 & 1 & 2,10 & 8 \\
\hline $230-240$ & 20,5 & 7.6 & 12 & 9 & 25 & 35 & 9 & 1 & 2,23 & 7 \\
\hline $240-250$ & 23,9 & 11,9 & 11 & 9 & 25 & 39 & 9 & 3 & 2,42 & 8 \\
\hline $250-260$ & 43,7 & 16,6 & 285 & 21 & 89 & 59 & 13 & 1 & 3,38 & 11 \\
\hline $260-270$ & 91,4 & 18,0 & 37 & 26 & 107 & 61 & 12 & 1 & 3,27 & 12 \\
\hline $270-290$ & 62,5 & 17.7 & 20 & 22 & 69 & 64 & 11 & 1 & 3,54 & 14 \\
\hline $290-310$ & 88,7 & 22,4 & 21 & 22 & 126 & 66 & 13 & 1 & 3,60 & 14 \\
\hline $310-330$ & 91,1 & 21,7 & 21 & 28 & 131 & 78 & 13 & 1 & 3,84 & 13 \\
\hline $330-350$ & 93,5 & 23,4 & 21 & 25 & 99 & 76 & 13 & 11 & 3,80 & 14 \\
\hline $350-370$ & 94,2 & 16,4 & 20 & 18 & 109 & 64 & 12 & 1 & 3,33 & 14 \\
\hline $370-390$ & 95,3 & 17,4 & 22 & 19 & 136 & 75 & 13 & 1 & 3,81 & 15 \\
\hline $390-410$ & 96,9 & 23,1 & 28 & 23 & 127 & 88 & 13 & 10 & 4,02 & 17 \\
\hline $410-430$ & 88,4 & 22,7 & 22 & 26 & 149 & 73 & 12 & 1 & 3,89 & 15 \\
\hline $430-450$ & 87.7 & 17,2 & 22 & 22 & 108 & 83 & 15 & 1 & 4.25 & 16 \\
\hline $450-470$ & 89,4 & 18,6 & 21 & 18 & 108 & 86 & 15 & 1 & 4,27 & 16 \\
\hline $470-490$ & 97,1 & 7,7 & 29 & 22 & 170 & 89 & 15 & 1 & 4,21 & 16 \\
\hline $490-510$ & 95,0 & 18,6 & 23 & 21 & 135 & 84 & 16 & 1 & 4,25 & 18 \\
\hline $510-530$ & 99,0 & 18,7 & 22 & 21 & 130 & 85 & 14 & 1 & 6,63 & 15 \\
\hline $530-550$ & 93,5 & 17,3 & 22 & 20 & 140 & 87 & 17 & 1 & 4,64 & 18 \\
\hline $550-570$ & 98,7 & 7.9 & 20 & 20 & 126 & 84 & 16 & 1 & 4,75 & 18 \\
\hline $570-590$ & 99,0 & 6,0 & 21 & 23 & 114 & 97 & 16 & 1 & 5,05 & 16 \\
\hline $590-610$ & 99,3 & 12,4 & 20 & 22 & 121 & 94 & 17 & 1 & 4,59 & 16 \\
\hline $610-630$ & 99,0 & 11,2 & 20 & 23 & 109 & 90 & 16 & 1 & 4,10 & 18 \\
\hline $630-700$ & 80,5 & 24,0 & 19 & 24 & 116 & 90 & 15 & 1 & 4,42 & 15 \\
\hline $700-720$ & 67,0 & 19,3 & 19 & 22 & 130 & 77 & 15 & 1 & 3,98 & 15 \\
\hline $720-740$ & 97,0 & 17,9 & 23 & 21 & 121 & 80 & 15 & 1 & 4,07 & 15 \\
\hline Backgrour & value $=$ & 17,3 & 22,4 & 22,2 & 121,9 & 80,5 & 14,3 & 1,9 & 4,2 & 15,5 \\
\hline Average + & 3 St.Dev & 32,9 & 34,7 & 29,8 & 181,8 & 110,8 & 19,5 & 10,3 & 6,3 & 20,4 \\
\hline
\end{tabular}

Table 1 - Heavy metals contamination at Fonte Bela core. 


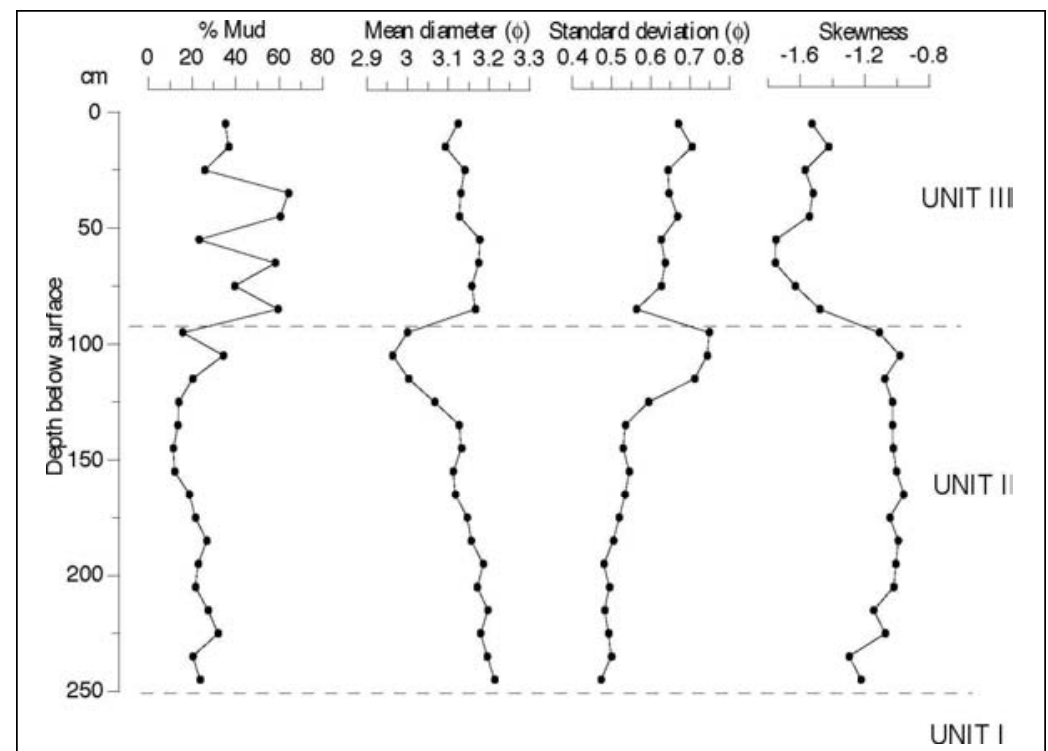

Figure 7. Vertical profile of Fonte Bela core: mud content and textual parameters of sand fraction.

Unit III (90 cm - surface) - The upper unit consists of alternating muddy sand and sandy mud, the mud content varying between $23 \%$ and $64 \%$ of the sample and averaging $45 \%$. The sand fraction is once again fine, moderately sorted and strongly negatively skewed. The oscillations found in the sand : mud ratio that exceeds the variations found in the intermediate unit, it is not translated into the vertical variation of the size distribution statistics of the sand fraction. In fact, the up core variation of the mean diameter and sorting index closely match the trends displayed by Unit II.

The location of the coring site in an agriculture farmland may influence the large amplitude oscillations found in the mud/sand content.

The opening of the irrigation ditch where the core was done exploit the contact between unites I and II, the first one with fine and massive sediments and the second mainly sandy.

The heavy metals contents show the influence of the sediments texture; the higher values corresponding to the increase of the silty-clayed content (Figure 8). The gold is the exception. The highest tenors were found in the deepest unit (I), decreasing in the unit II and increasing again in the surface unit (III). About the $250 \mathrm{~cm}$ deep, between units II and I, there is always a peak or a clear increase of all chemical elements (as well as about an increase of $20 \%$ of the silty-clayed fraction). Besides the texture effect, the presence of the bottom of the ditch at this level is the main reason to explain the increase of tenors at $250 \mathrm{~cm}$. The water stored in the irrigation ditch comes from the superficial soil wash of vineyards. The 


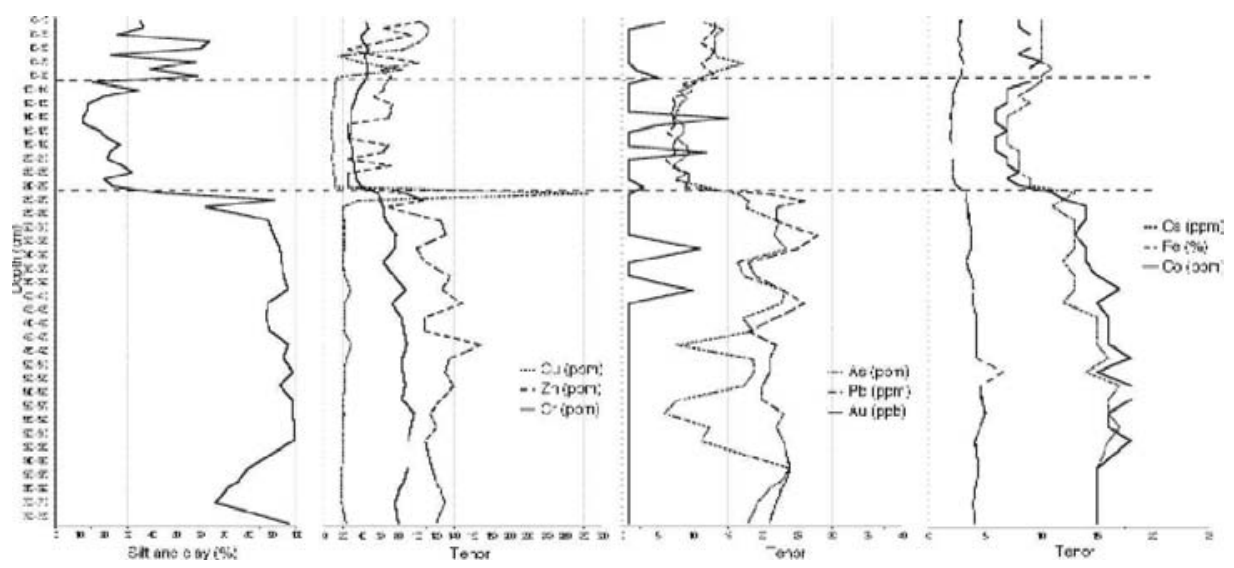

Figure 8 - Heavy metals contents fo Fonte Bela core.

vineyards are usually submitted to copper sulphate that contaminates the water and it is responsible for the $\mathrm{Cu}$ peak that reached $285 \mathrm{ppm}$ at the bottom of the ditch (between 250 and $260 \mathrm{~cm}$ ). The $\mathrm{Cu}$ value decreases to $37 \mathrm{ppm}$ (at $260-270 \mathrm{~cm}$ ) despite the increase of the silty-clayed fraction (from $44 \%$ at $250-260 \mathrm{~cm}$ to $91 \%$ at $260-270 \mathrm{~cm}$; table 1 ).

All the values, except $\mathrm{Cu}$, are below the threshold values of heavy metals in alkaline agriculture soils ( $\mathrm{pH}$ from 7.9 to 8.3) established by the European and Portuguese legislation (table 1). Besides the high $\mathrm{Cu}$ value at the bottom of the ditch, the $\mathrm{Cu}$ values are always higher between $80 \mathrm{~cm}$ and the surface independently of sediment texture, namely in the first $40 \mathrm{~cm}$, where the $\mathrm{Cu}$ is always above $100 \mathrm{ppm}$. Taking into account that the threshold value for $\mathrm{Cu}$ in soils with $5.5<\mathrm{pH}<7.0$ is $100 \mathrm{ppm}$ (this value is $200 \mathrm{ppm}$ in soils with $\mathrm{pH}>7.0$ and with agriculture for animal consumption, which is not the case), the founded content show a clear $\mathrm{Cu}$ contamination in the LT alluvial soils.

\section{Sedimentological and geochemical analysis of Quinta da Boavista core}

The results of Quinta da Boavista core show a clearly decreasing trend in the fine sedimentation through time (table 2).

The sedimentological as well as the geochemical study of the core allowed the definition of three major sedimentary units (Units I to III) - Figure 9.

Unit I $(370-230 \mathrm{~cm})$ - The basal unit consists essentially of muddy sands and sandy mud, the mud content averaging $48 \%$ of the total sample (from 36 to 59\%). The sand component is fine, moderately sorted and always positively skewed (Figure 9).

Unit II $(230-68 \mathrm{~cm})$ - The intermediate unit consists of slightly muddy sands to sandy mud, the mud content averaging $28 \%$ of the total sample (from 9 to $45 \%$ ). The sand component is again fine and moderately sorted; the skewness parameter indicates predominance of positive values but a few symmetrical or negatively skewed samples occur (Figure 9). 


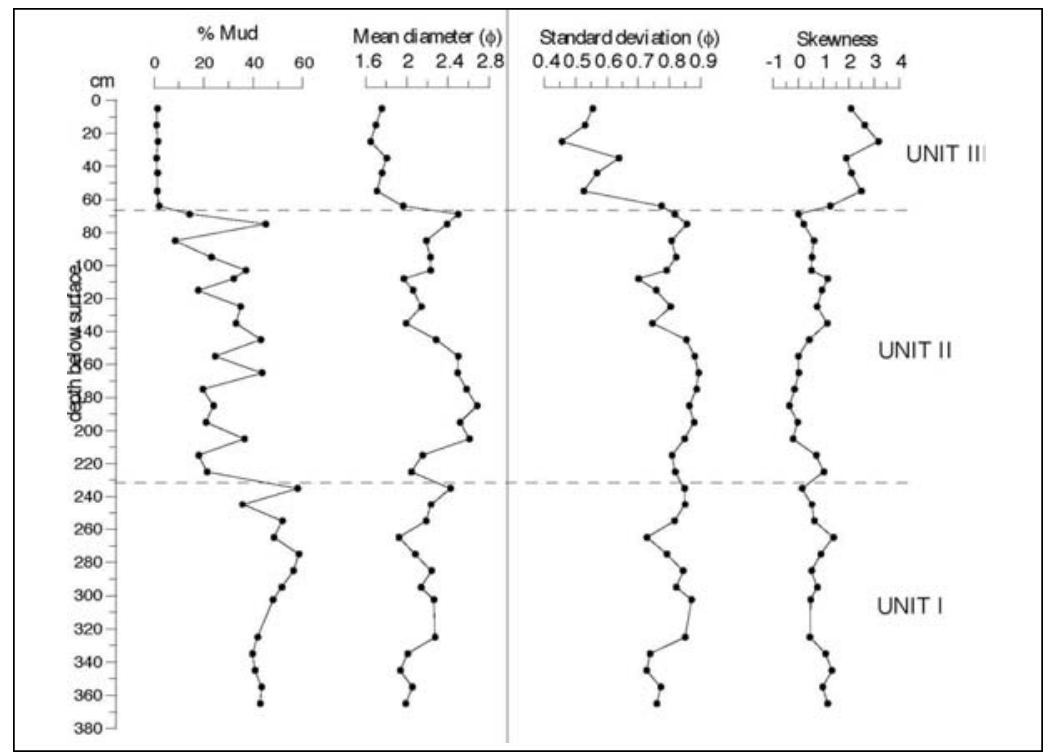

Figure 9 - Vertical profile of Quinta da Boavista core: mud content and extual parameters of sand fraction.

Unit III ( $68 \mathrm{~cm}$ - surface) - The upper unit consists of clean to slightly muddy sands, the sand content always reach $98 \%$. Sediment is represented by medium, moderately sorted (although better sorted than units I and II) and strongly positively skewed sand. The amplitude of the sorting index exceeds by a factor of two the equivalent range found in both the basal and intermediate units and decreases upcore (Figure 9).

The sand : mud ratio varies within each sedimentary unit defining a number of positive and negative oscillations around the mean, with fairly constant amplitude. Yet, the transitions between adjacent units are characterized by sharp drops of the mud proportion, which shows a general decreasing trend towards the top of the column (Figure 9).

In general, the grain size distribution of the sand fraction shows positive skewness.

\section{Comparison of the two cores results}

The sedimentary column of Quinta da Boavista and Fonte Bela sites shares a threefold architecture, the transition between the lower and intermediate units in both sites being characterized by a marked decrease of the mud proportion. The top units are not comparable in this respect because Quinta da Boavista represents marginal channel sedimentation while Fonte Bela lies within the floodplain. The contrasting textural signatures of sediments cored in both sites (Figure 11) indicate that hydrodynamics, sediment sources or location relative to the main distributaries were different.

In what concerns the mineralogy of the sand's heavy fraction, very similar assemblages were found along both profiles: andalusite, tourmaline, zircon, sillimanite (fibrous and granular), green hornblende, garnet, staurolite and disthene. 


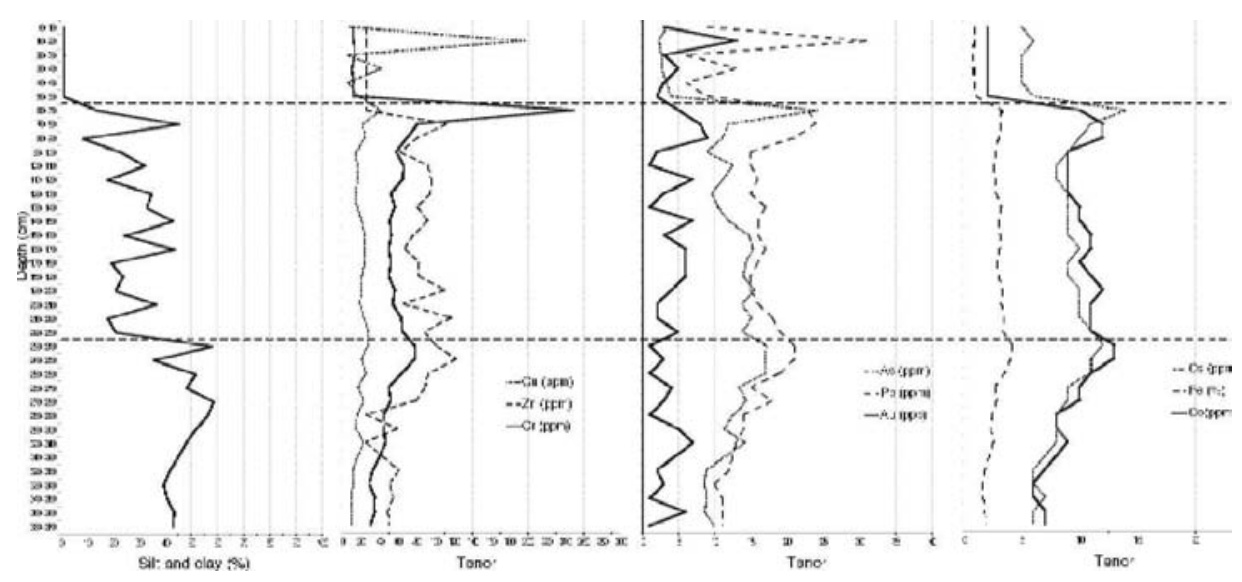

Figure 10 - Heavy metals contents of Quinta da Boavista core.

However, since the Fonte Bela (FB) assemblage clearly shows depositional episodes of very weak energy of flux, expressed by very high contents in biotite (often euhedrical) and less dense minerals, Quinta da Boavista (QB) presents higher concentration of denser grains such as garnets and zircons, rare biotite and some grains of apatite.

All the grains are quite angulous showing slight maturity of sediments and short distance of transport, exception made to well-rounded garnet grains.

In a sedimentological study of the Tagus estuary (Oliveira, 1967), the heavy minerals were analyzed with great detail and 7 different assemblages were found. One of them, "assemblage B", was just the same that was found in this work and its area of distribution is «almost all of the estuary», which means that it is the most ubiquitous of all.

Trying to find the rock source of these minerals, the author sampled the area upstream of the estuary, one of the samples being picked just in Santarém. The assemblage was again the same including the green hornblende and garnet. Once in the proximity of the estuary there are no rocks containing these two minerals; the explanation can only be the supply in the metamorphic rocks of the «Shale and greywacke Complex» (C.X.G.) that occurs in a more upstream segment of the river. The "assemblage C" - tourmaline, andalusite and staurolite with almost total lack of hornblende and garnet - is in turn originated in the continental Miocene and Pliocene sediments of the left bank of the estuary.

Comparing these conclusions with the FB and QB profiles, it becomes clear that the sources of the heavy minerals found in both profiles are: a) the Paleozoic high-grade metamorphic rocks of the "Blastomylonitic zone", preferably from the C.X.G. and localized downstream from it, for biotite, staurolite, silimanite, green hornblende, andalusite, angulous garnet, zircon and kainite; b) the sediments of the Tertiary Basin, that were in turn derived from the granitic and pegmatitic rocks of the Niza region (left margin), for tourmaline, andalusite and rounded garnet. 
Late holocene evolution of the lower Tagus alluvian plain and heavy metals content: preliminary results

\begin{tabular}{|c|c|c|c|c|c|c|c|c|c|c|}
\hline \multirow[b]{2}{*}{ Depth $(\mathrm{cm}$} & \multirow[b]{2}{*}{$\begin{array}{c}\text { Silt+clay } \\
(\%)\end{array}$} & \multicolumn{4}{|c|}{ Chalcophiles } & \multicolumn{2}{|c|}{ Lithophiles } & \multicolumn{3}{|c|}{ Siderophiles } \\
\hline & & As (ppm) & $\begin{array}{c}\mathrm{Cu} \\
(\mathrm{ppm})\end{array}$ & $\begin{array}{c}\mathrm{Pb} \\
(\mathrm{ppm})\end{array}$ & $\begin{array}{c}\mathrm{Zn} \\
(\mathrm{ppm})\end{array}$ & $\begin{array}{c}\mathrm{Cr} \\
\text { (ppm) }\end{array}$ & Cs (ppm) & Au (ppb) & $\begin{array}{l}\mathrm{Fe} \\
(\%) \\
\end{array}$ & $\begin{array}{c}\mathrm{Co} \\
\text { (ppm) }\end{array}$ \\
\hline $0-10$ & 1,4 & 3,3 & 7 & 9 & 25 & 12 & 5 & 3 & 0,83 & 2 \\
\hline $10-20$ & 1,0 & 2,3 & 197 & 31 & 25 & 12 & 6 & 13 & 0,87 & 2 \\
\hline $20-30$ & 1,5 & 2,7 & 5 & 6 & 25 & 14 & 5 & 3 & 0,72 & 2 \\
\hline $30-40$ & 1,0 & 2,7 & 42 & 13 & 25 & 10 & 5 & 5 & 0,80 & 2 \\
\hline $40-48$ & 1,4 & 3,3 & 6 & 6 & 25 & 12 & 5 & 3 & 0,85 & 2 \\
\hline $50-60$ & 1,3 & 3,9 & 18 & 9 & 25 & 12 & 6 & 2 & 0,99 & 2 \\
\hline $60-67,5$ & 2,0 & 6,5 & 9 & 9 & 25 & 38 & 8 & 43 & 1,30 & 4 \\
\hline $67,5-70$ & 14,3 & 24,3 & 41 & 23 & 25 & 250 & 14 & 5 & 3,26 & 10 \\
\hline $70-80$ & 45,1 & 11,9 & 22 & 24 & 113 & 81 & 11 & 8 & 3,16 & 12 \\
\hline $80-90$ & 8,5 & 11,1 & 24 & 21 & 81 & 70 & 10 & 9 & 2,99 & 12 \\
\hline $90-100$ & 23,2 & 8,9 & 15 & 15 & 62 & 58 & 9 & 2 & 2,76 & 9 \\
\hline $100-110$ & 32,2 & 12,5 & 16 & 15 & 92 & 66 & 8 & 1 & 2,53 & 9 \\
\hline $110-120$ & 17,9 & 11,2 & 17 & 16 & 96 & 65 & 8 & 7 & 2,75 & 9 \\
\hline $120-130$ & 35,0 & 9,6 & 14 & 15 & 95 & 52 & 9 & 3 & 2,74 & 9 \\
\hline $130-140$ & 33,0 & 10,5 & 16 & 17 & 81 & 56 & 9 & 1 & 3,24 & 10 \\
\hline $140-150$ & 43,1 & 11,9 & 21 & 16 & 92 & 51 & 9 & 7 & 2,97 & 10 \\
\hline $150-160$ & 24,7 & 14,7 & 24 & 16 & 77 & 53 & 9 & 3 & 3,07 & 11 \\
\hline $160-170$ & 43,6 & 15,3 & 24 & 17 & 67 & 50 & 10 & 6 & 3,08 & 11 \\
\hline $170-180$ & 19,7 & 14,3 & 24 & 16 & 83 & 52 & 9 & 6 & 2,85 & 10 \\
\hline $180-190$ & 24,0 & 14,0 & 21 & 15 & 82 & 50 & 9 & 6 & 2,98 & 11 \\
\hline $190-200$ & 21,0 & 15,5 & 20 & 15 & 111 & 56 & 10 & 4 & 3,29 & 12 \\
\hline $200-210$ & 36,5 & 13,7 & 19 & 16 & 65 & 54 & 10 & 2 & 3,20 & 11 \\
\hline $210-220$ & 18,1 & 15,1 & 23 & 18 & 118 & 63 & 10 & 2 & 3,40 & 11 \\
\hline $220-230$ & 21,4 & 13,8 & 28 & 19 & 88 & 65 & 11 & 5 & 3,32 & 11 \\
\hline $230-240$ & 58,0 & 17,1 & 27 & 21 & 101 & 78 & 12 & 1 & 4,17 & 13 \\
\hline $240-250$ & 35,7 & 17,0 & 21 & 21 & 123 & 78 & 11 & 3 & 4,04 & 13 \\
\hline $250-260$ & 51,9 & 17,0 & 25 & 19 & 93 & 64 & 11 & 1 & 3,54 & 11 \\
\hline $260-270$ & 48,4 & 13,4 & 17 & 15 & 89 & 50 & 9 & 4 & 2,69 & 10 \\
\hline $270-280$ & 58,5 & 14,4 & 23 & 18 & 80 & 52 & 9 & 3 & 2,86 & 10 \\
\hline $280-290$ & 56,3 & 12,6 & 16 & 14 & 25 & 45 & 8 & 1 & 2,46 & 8 \\
\hline $290-300$ & 51,6 & 11,3 & 15 & 14 & 59 & 44 & 8 & 5 & 2,26 & 8 \\
\hline $300-305$ & 48,1 & 14,2 & 23 & 13 & 25 & 47 & 8 & 7 & 2,57 & 9 \\
\hline $320-330$ & 41,8 & 8,8 & 11 & 12 & 61 & 33 & 6 & 2 & 1,82 & 7 \\
\hline $330-340$ & 39,8 & 8,6 & 11 & 10 & 51 & 29 & 6 & 3 & 1,57 & 6 \\
\hline $340-350$ & 40,8 & 8,9 & 9 & 11 & 55 & 35 & 7 & 1 & 1,64 & 6 \\
\hline $350-360$ & 43,5 & 8,6 & 9 & 11 & 49 & 35 & 6 & 6 & 1,79 & 7 \\
\hline $360-370$ & 42,9 & 9,8 & 9 & 11 & 51 & 30 & 6 & 1 & 1,89 & 7 \\
\hline Backgrour & value $=$ & 17,3 & 22,4 & 22,2 & 121,9 & 80,5 & 14,3 & 1,9 & 4,2 & 15,5 \\
\hline Average + & St.Dev & 32,9 & 34,7 & 29,8 & 181,8 & 110,8 & 19,5 & 10,3 & 6,3 & 20,4 \\
\hline
\end{tabular}

Table 2 - Heavy metals contamination at Quinta da Boavista core. 


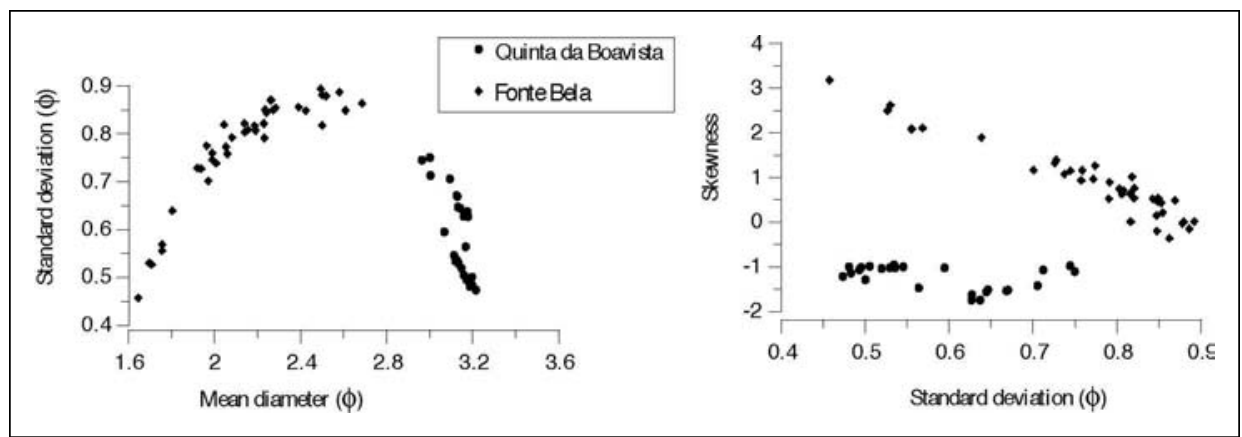

Figure 11 - plot of grain size distribution statistics (sand fraction) of sediments from Quinta da Boavista and Fonte Bela.

The methodological approach use in heavy metal analysis allow to recognize the $\mathrm{Cu}$ contamination in the superficial $50 \mathrm{~cm}$ of the soil at Fonte Bela (table 1), where the tenors exceed 4 to 5 times the background value. Between 60 and $80 \mathrm{~cm}$ deep it reach 2 to 4 times the background value. At the bottom of the ditch, between 250 and $270 \mathrm{~cm}$, the contamination is 13 times the background value.

At Quinta da Boavista (table 2) the $\mathrm{Cu}, \mathrm{Pb}$ and $\mathrm{Cr}$ contamination can be recognized in the superficial $70 \mathrm{~cm}$ : $68 \mathrm{~cm}$ belong to the surface sandy unit and $2 \mathrm{~cm}$ to the unit II (where the silty-clayed fraction increase from $2 \%$ to $14 \%$ ). This concentration shows not only the contamination but also the vertical migration of these elements and its retention by the silty-clayed fraction. At 10 and $20 \mathrm{~cm}$ the $\mathrm{Cu}$ contamination reach 9 times the background value and between $30-40 \mathrm{~cm}$ and $68-70 \mathrm{~cm}$ this value is twice higher. The $\mathrm{Pb}$ is 1.4 times the background value between 10 and $20 \mathrm{~cm}$. The $\mathrm{Cr}$ reaches $250 \mathrm{ppm}$ between 68 and $70 \mathrm{~cm}$, i.e., 3 times the background value. The $\mathrm{Cr}$ highest values in this site can be related to the vicinity of the Tagus tributary River Alviela mouth, where tanning industries where settled.

If we compare these results with those obtained by Freitas et al (1999), in the Seixal marsh of the Tagus estuary, we notice that the $\mathrm{Zn}$ and the As go along with the referred heavy metals and that they are related to chemical and metal-mechanic industries settled in the estuary.

\section{Conclusions}

Both cores whether they are placed in the Tagus main channel (Quinta da Boavista) or whether they are $2.5 \mathrm{~km}$ far from it in the alluvial plain show 3 sedimentological units. As several authors have mentioned before (Marriott, 1992; Asselman \& Middelkoop, 1995), there is a relation between the morphology of the alluvial plain that frame the cores and the spatial textural variation of the sediments. In the studied case the sedimentological changes can be ascribed to lateral migration of the fluvial channel in the flood plain. 
At Quinta da Boavista, in the right bank of a concave meander of the main channel, the decrease of the fine sedimentation through time (from $48 \%$ to $1 \%$, between units I and III) is probably related to the forthcoming of the main channel, in an environment of increasing energy and a decrease of the fine sedimentation. The traces of the old channels on the left bank add to this conclusion.

The 3 chronological data that was possible to obtain (due to the very low organic matter content), all in unit II, probably belong to a forthcoming of the main channel environment. They show an irregular sedimentation rate. The data were obtained from sediments at $163 \mathrm{~cm}, 133 \mathrm{~cm}$ and $129 \mathrm{~cm}$ deep and the results have been $4020 \pm 40 \mathrm{BP}, 3920$ $\pm 40 \mathrm{BP}$ and $3480 \pm 40 \mathrm{BP}$. The different evaluated sedimentation rates are of $3 \mathrm{~mm} / \mathrm{year}$ between 163 and $133 \mathrm{~cm}$ and $0.1 \mathrm{~mm} /$ year between 133 and $129 \mathrm{~cm}$.

At Fonte Bela, the higher silty-clayed fraction (90\%) in the older unit (I) shows a more calm sedimentation environment, with low energy, like a lake or a swamp (?), sheltered from the main channel by a bar. In the unit II the silty-clayed fraction decreases to $21 \%$, showing a clear rupture with the previous conditions, now in a more energetic environment (very similar to the unit II of Quinta da Boavista). The unit I witness the present conditions, i.e., the environment of the alluvial plain far from the main channel and from the bar deposits, where the fine sedimentation is higher $(45 \%)$.

The 3 chronological data reveal the following results: $70 \pm 40 \mathrm{BP}$ at $30 \mathrm{~cm}$ deep, $1090 \pm 70 \mathrm{BP}$ at $70 \mathrm{~cm}$ and $3400 \pm 40 \mathrm{BP}$ at $740 \mathrm{~cm}$. The values show once again very different sedimentary rates: $2.9 \mathrm{~mm} /$ year between 740 and $70 \mathrm{~cm}$ deep; $0.4 \mathrm{~mm} /$ year between 70 and $30 \mathrm{~cm}$, and $2.5 \mathrm{~mm} /$ year between $30 \mathrm{~cm}$ and the surface.

The heavy metals tenors show an increasing and diversified contamination of the fluvial sediments ( $\mathrm{Cu}$ due to cooper sulphate vineyards) as well as the irrigation ditches and fluvial channels (with higher tenors in $\mathrm{Cu}, \mathrm{Pb}$ due to oil contaminants and $\mathrm{Cr}$ from the tanning industries). In the marshes downstream, the $\mathrm{Cu}$ tenors decrease while the $\mathrm{Zn}$ and As increase due to the chemical industries settled along the estuary.

\section{References}

Asselman, N.E.M.and Middelkoop, H. (1995). Floodplain sedimentation: quantities, patterns and processes. Earth Surface Processes and Landforms, 20 (6): 481-499.

Ansari, A.A., Singh, I.B. and Tobschall, H.J. (2000). Importance of geomorphology and sedimentation processes for metal dispersion in sediments and soils of the Ganga Plain: identification of geochemical domains. Chemical Geology, 162: 245-266.

Aswathanarayana, U. (1995). Geoenvironment. An introduction. A.A. Balkema, Brookfield, Rotterdam.

Folk, R.L. and Ward, W.C. (1957). Brazos River Bar: a study in the significance of grain size parameters. Journal of Sedimentary Petrology, 27(1): 3-26.

Freitas, M.C., Andrade, C., Moreno, J.C., Munhá, J.M. and Cachão, M. (1999). The sedimentary record of recent (last 500 years) environmental changes in the Seixal Bay marsh, Tagus estuary, Portugal. Geologie en Mijnbouw, 77: 283-293. 
C. Ramos, E. Reis, A. Ramos Pereira, T.M. Azevedo, E. Nunes, M.C. Freitas \& C. Andrade

Marriott, S. (1992). Textural analysis and modelling of a flood deposit. Earth Surface Processes and Landforms, 17 (7): 687-697.

Stuiver, M. Long, A., Kra, R.S. and Devine, J.M. (1993). Calibration - 1993. Radiocarbon, 35.

Talma, A.S. and Vogel, J.C. (1993). A simplified approach to calibrating C14 dates. Radiocarbon, 35: 317-322.

Vogel, J.C., Fuls, A., Visser, E. and Becker, B. (1993) - Pretoria Calibration Curve for Short Lived Samples. Radiocarbon, 35: 73-86. 